\title{
Sensory wspomagające zrobotyzowane spawanie elementów wielkogabarytowych i spoin wielościegowych
}

\author{
Sensors supporting the large-size structure robotic welding \\ and multipass welding process
}

\section{Streszczenie}

W artykule przedstawiono narzędzia programistyczne, a szczególnie różne typy sensorów wspomagających zrobotyzowane spawanie elementów wielkogabarytowych.

Słowa kluczowe: sensor dotyku; sensor tuku; sensor laserowy; system wizyjny

\section{Abstract}

This article present software tools and especially different types of sensors which support large-size structure robotic welding process.

Keywords: touch sensor; arc sensor; laser sensor; vision system

\section{Wstęp}

Wśród robotów przemysłowych bardzo ważną grupę stanowią roboty przeznaczone do procesów spawalniczych.

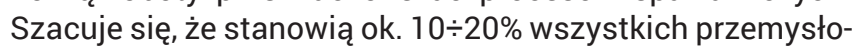
wych zastosowań robotów. Najpowszechniej robotyzacja stosowana jest $w$ procesach spawania elektrodą topliwą w osłonie gazu (MIG/MAG) w produkcji wielkoseryjnej [1].

W grupie robotów spawalniczych do spawania metodami MIG/MAG znaczącą pozycję zajmuje spawanie elementów wielkogabarytowych ze spoinami wielościegowymi [2] (rys. 1).

W celu umożliwienia spawania złączy ze spoinami wielościegowymi producenci robotów spawalniczych opracowali szeroką gamę sensorów. W niniejszym artykule omówiono sensory w oparciu o rozwiązania firmy PANASONIC.

\section{Nowy sensor dotyku [3]}

Najnowsza wersja sensora dotyku firmy PANASONIC dedykowana jest specjalnie do aplikacji zrobotyzowanych, w których zachodzi potrzeba użycia dużej ilości punktów szukania przesunięć elementu spawanego. Software niniejszego sensora zawiera bibliotekę z bogatą gamą ruchów robota zarówno względem układu narzędzia, jak i układu globalnego. Po wstawieniu komendy z odpowiednim kierunkiem ruchu ramię robota zaczyna wykonywać operację szukania do momentu wykrycia detalu. W chwili dotknięcia ramię jest automatycznie zatrzymywane, a punkt z aktualną pozycją zapisywany. Na rysunkach $2 \mathrm{a}$ i $2 \mathrm{~b}$ przedstawiono fragment programu zawierający kompletną sekwencję szukania;

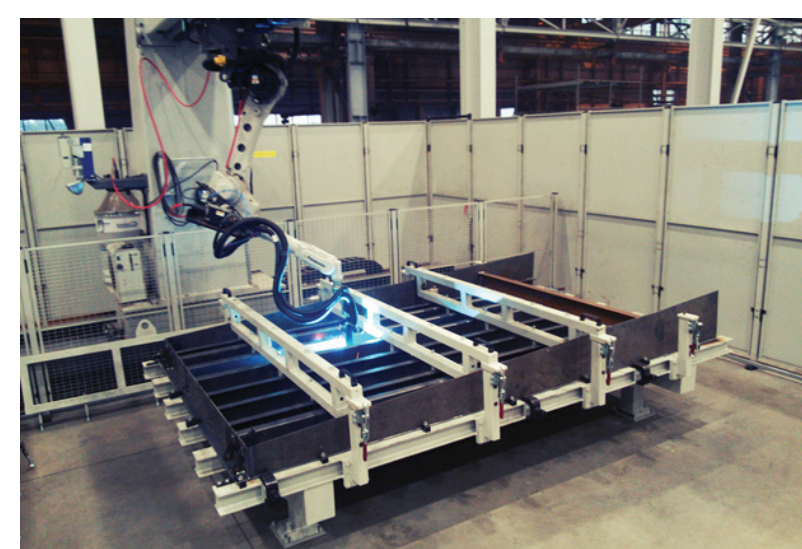

Rys. 1. Zrobotyzowane stanowisko do spawania elementów wielkogabarytowych

Fig. 1. Robotic system for welding large-size structures

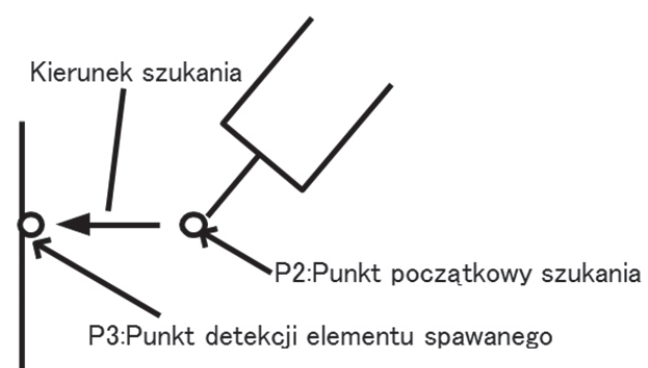

Rys. 2a. Zasada działania nowego sensora dotyku z automatyczną detekcją punktu styku

Fig. 2a. The principle of operation of touch sensor with automatic detection of contact point

Inż. Mirosław Nowak (IWE); mgr inż. Jacek Buchowski, mgr inż. Daniel Wiśniewski (IWE) - TECHNIKA SPAWALNICZA.

Autor korespondencyjny/Corresponding author: miroslaw.nowak@techspaw.com.pl 


\section{1: Mech1: Robot+G4, Weld1 \\ Begin 0f Program \\ REF MNU 0 \\ REF SLS 0 \\ $\mathrm{TOOL}=1: \mathrm{T} 00 \mathrm{~L} 01$ \\ - MOVEP P1 (0), 50.00m/min \\ - MOVEP P2(0), 50. 00m/min SLS TCH 14, $0,0,0$, \\ - MOVEL P3(0), 50.00m/min \\ End of Program}

Rys. 2b. Fragment programu z sekwencją nowego sensora dotyku Fig. $\mathbf{2 b}$. Part of program code with new Touch Sensor sequence

punkt początkowy operacji szukania P2, następnie komendę SLS TCH 14, która zawiera informację o kierunku szukania oraz punkt P3 automatycznie dodany przez algorytm sensora dotyku.

Takie rozwiązanie znacznie przyspiesza pisanie programu z wykorzystaniem rzeczywistego stanowiska zrobotyzowanego.

Dodatkowo dla polepszenia przejrzystości kodu programu wprowadzono numerację zapisanych przesunięć. W przykładzie na rysunku 3 dodano do punktu spawania P13 wartość przesunięcia nr 40. Sama wartość przesunięcia została utworzona trzy linijki wcześniej w komendzie SLS TCH 40.

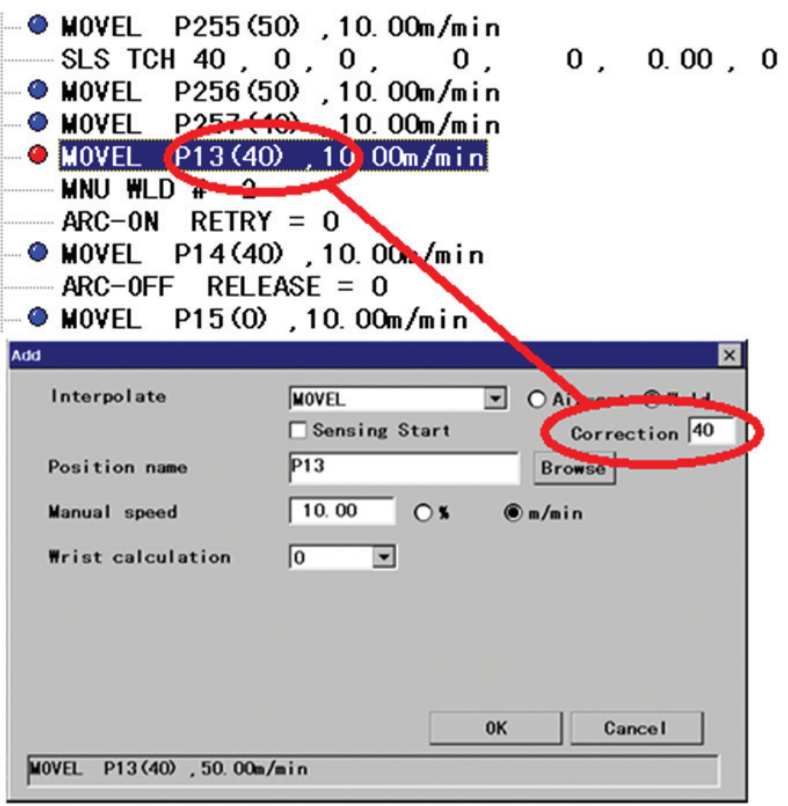

Rys. 3. Przykładowa numeracja przesunięć sensora dotyku Fig. 3. Example numeration of Touch Sensor shift

\section{Sensor dotyku standardowy - Touch sensor function [3]}

Ten sensor zawiera podstawowe biblioteki ruchu ramienia robota (rys. 4) wykrywające detal spawany. Mamy możliwość poruszania się w układzie robota $\mathrm{X}+, \mathrm{X}-, \mathrm{Y}+, \mathrm{Y}-\mathrm{Z}, \mathrm{Z}+\mathrm{Z}$ - oraz układzie narzędzia $T+, T$ - (kierunek rzutowany na płaszczyznę $\mathrm{X}, \mathrm{Y}$ robota), Tp+, Tp- (prostopadłe do T+ i T-), Tf (kierunek wzdłuż osi narzędzia - drutu spawalniczego), Tv+,Tv- (kierunek prostopadły do osi narzędzia).

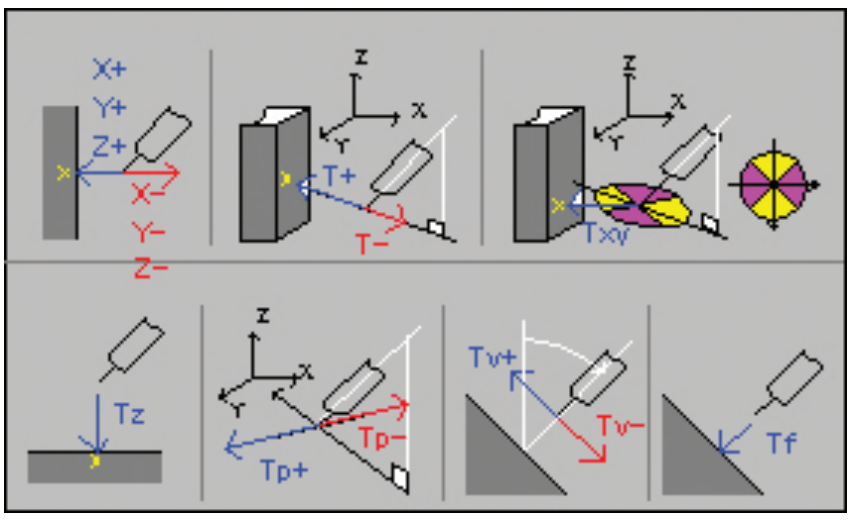

Rys. 4. Rodzaje ruchu standardowego sensora dotyku Fig. 4. Movement type of standard Touch Sensor

\section{Sensor dotyku dla blach ukosowanych - Groove Touch Sensor Function [3]}

Wersja rozszerzona sensora umożliwia dodatkowo wykrywanie ukosowania. Pozwala to na dokładne zlokalizowanie złącza i określenie wielkości rowka spawalniczego (rys. 5). Pomiar odbywa się poprzez dotknięcie drutem charakterystycznych punktów detalu. Aby pomiar był jak najbardziej dokładny drut podczas pomiaru blokowany jest za pomocą siłownika pneumatycznego w specjalnie skonstruowanym uchwycie spawalniczym (rys. 6)[4]. Firma TECHNIKA SPAWALNICZA w budowanych systemach zrobotyzowanych stosuje uchwyty spawalnicze z pneumatycznym dociskiem drutu w oparciu o rozwiązania firmy DINSE lub PANASONIC.

W rozwiązaniu firmy PANASONIC dodatkowo zainstalowano siłowniki w podajniku drutu, które dociskają rolki tak, aby drut się nie przemieszczał [3].
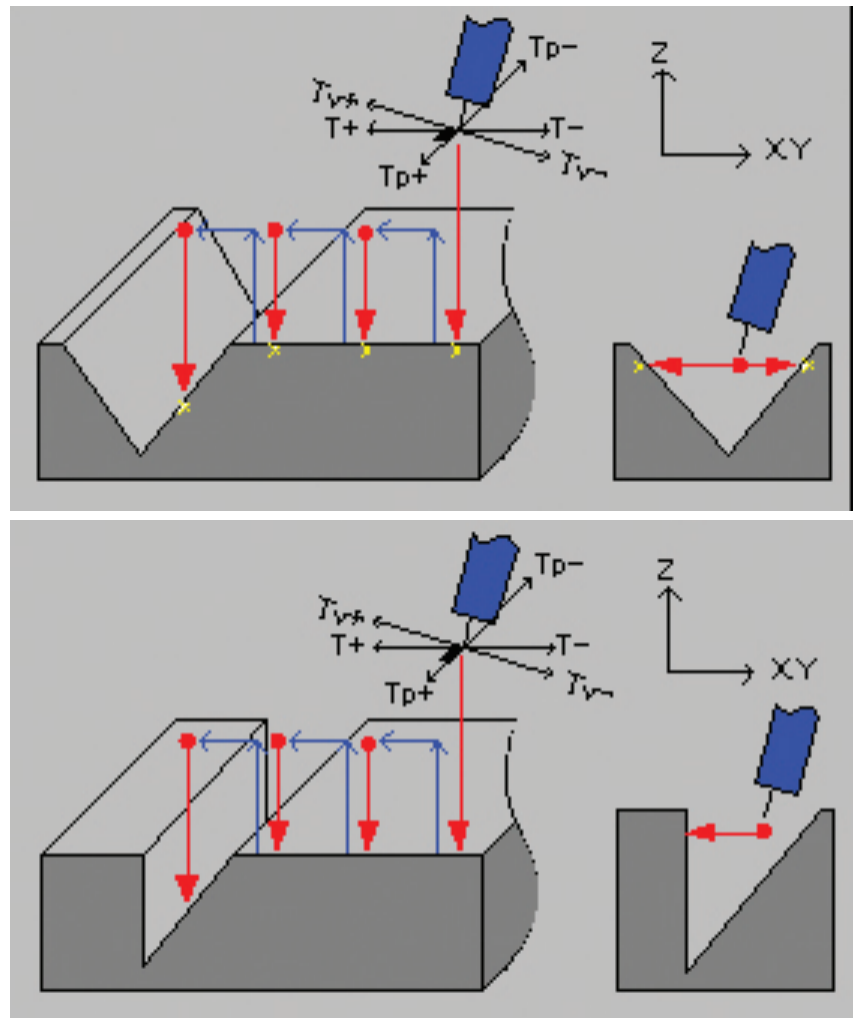

Rys. 5. Sekwencja ruchu rozszerzonego sensora dotyku dla blach ukosowanych

Fig. 5. Movement sequence of extended Touch Sensor for beveled plates 

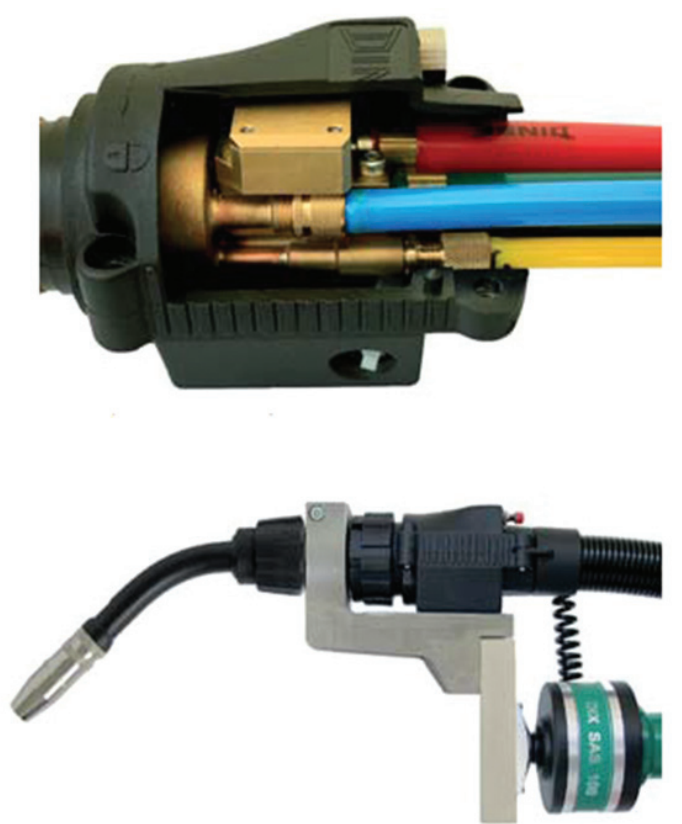

Rys. 6. Uchwyt spawalniczy DINSE z pneumatycznym dociskiem drutu spawalniczego

Fig. 6. DINSE Welding torch with pneumatic wire clamp

\section{Funkcja Thick Plate - programowanie spoin wielościegowych [3]}

Istnieją dwa sposoby programowania spoin wielościegowych. Pierwsza, standardowa zakłada napisanie każdego ściegu osobno, druga zakłada użycie specjalnych funkcji generujących ściegi automatycznie. W tym celu firma PANASONIC opracowała innowacyjny software Thick Plate. Ideą tego rozwiązania jest napisanie przez programistę jedynie pierwszego ściegu, na podstawie którego automatycznie tworzone są kolejne. Algorytm ten uwzględnia zmianę kąta palnika i jego przesunięcie w kolejnych ściegach (rys. 7).

Thick Plate umożliwia również spawanie złącza o nierównomiernej szerokości rowka spawalniczego. Częstotliwość ruchu oscylacyjnego dopasowuje się wówczas do zmiennej szerokości złącza (rys. 8).

\section{Sensor łuku - Arc sensor function [3]}

Wykorzystanie sensora łuku na stałe powiązane jest z ruchem oscylacyjnym palnika wykonywanym podczas spawania pomiędzy dwoma elementami. Robot w tym czasie dokonuje pomiaru wartości natężenia prądu oraz napięcia łuku. Jeżeli elementy są przesunięte względem pierwotnej

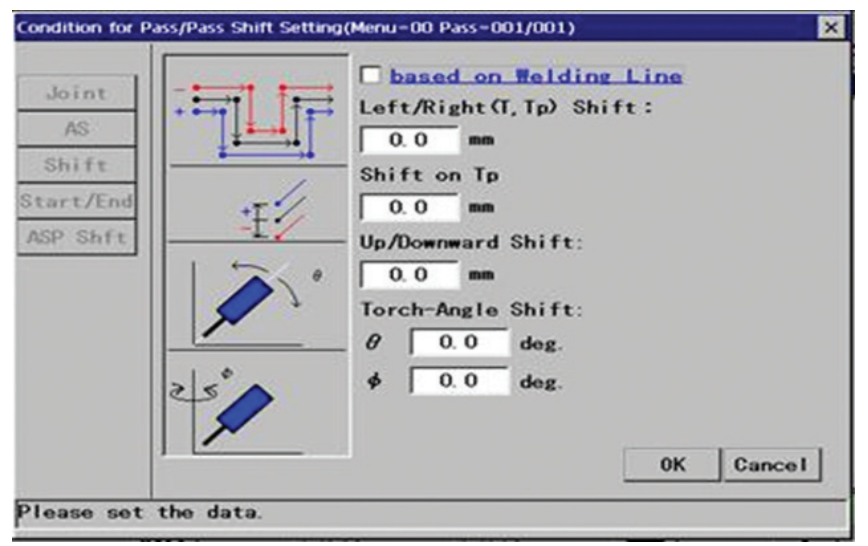

Rys. 7. Okno z parametrami funkcji Thick Plate Fig. 7. Thick Plate function parameters window
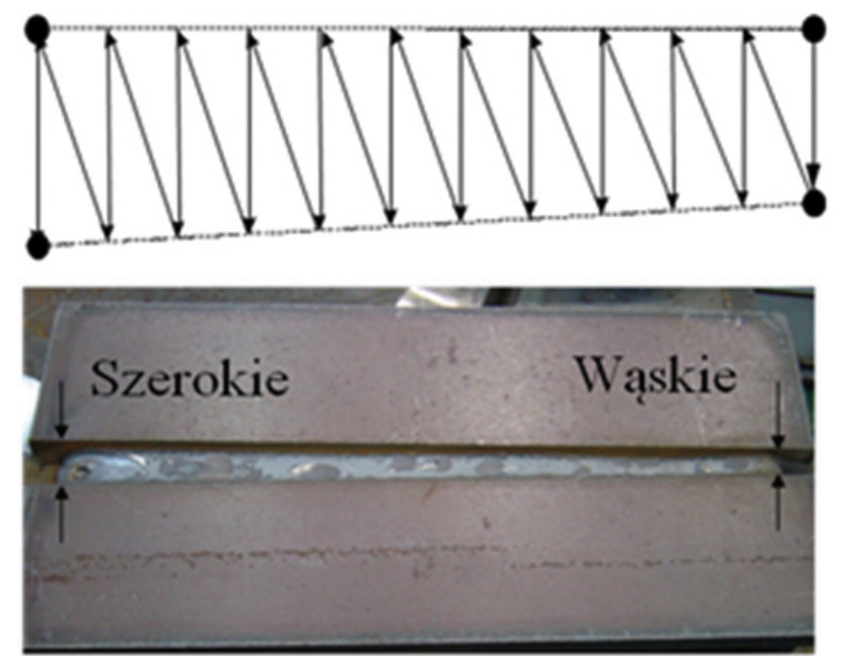

Rys. 8. Złącze wąskie w początkowym odcinku, szerokie w końcowym odcinku

Fig. 8. Narrow joint at first section, wide at the end

trajektorii ruchu ramienia robota, długość wolnego wylotu elektrody podczas wykonywania oscylacji wzrośnie, lub zmaleje w zależności od kierunku przesunięcia (rys. 9). W przypadku skrócenia łuku opór elektryczny zmaleje, co spowoduje zgodnie z poniższym wzorem wzrost wartości natężenia prądu [5]:

$$
\mathrm{I}=\mathrm{U} / \mathrm{R} \text {, }
$$

gdzie:

I - wartość natężenia prądu

$\mathrm{U}$ - napięcie elektryczne

$\mathrm{R}$ - opór elektryczny

Natomiast jeżeli długość wolnego wylotu elektrody zostanie wydłużona, nastąpi sytuacja odwrotna. Dużą zaletą sensora łuku jest możliwość jego pracy w trakcie trwania procesu np. gdy podczas spawania element pod wpływem naprężeń termicznych zaczyna się odkształcać, a tym samym trajektoria ruchu ramienia robota zaczyna się przesuwać. W takim przypadku robot na bieżąco koryguje ścieżkę poprzez pomiar natężenia prądu i utrzymuje środek oscylacji dokładnie w środku złącza.

Sensor łuku z powodzeniem możemy wykorzystać w złączach kątowych oraz doczołowych z fazowaniem. Dla prawidłowej i stabilnej pracy zalecany jest prąd spawania co najmniej $200 \mathrm{~A}$ oraz zalecany łuk pulsacyjny. Dlatego też znajduje on zastosowanie przy spajaniu elementów wielkogabarytowych, gdzie grubości blach są powyżej $3 \mathrm{~mm}$ odpowiednio dla złączy kątowych oraz powyżej $5 \mathrm{~mm}$ dla złączy doczołowych z fazowaniem. Sensor łuku nie może być wykorzystany przy łączeniu cienkich blach (prąd spawania poniżej 200 A) oraz w złączach przylgowych lub doczołowych bez fazowania. W takich przypadkach nie jest możliwe wykonanie pomiaru ruchem oscylacyjnym. Dlatego do wykrycia np. linii spoiny zakładkowej konieczne jest zastosowanie innego typu sensorów jak np. laserowego, opisanego poniżej.

\section{Sensor laserowy - Laser sensor function [3]}

W przypadku sensorów laserowych możemy mówić o większej uniwersalności tych urządzeń, ponieważ znajdują zastosowanie zarówno w przypadku spawania elementów cienkościennych, jak i grubych. Zwiększa to znaczenie zakres detekcji przy jednoczesnych zachowaniu dokładności wykrywania sięgającej 0,3 mm, gdy sensor zamocowany jest na ramieniu robota (dokładność robota 0,1 mm).

Zasada działania sensora (rys. 10) polega na emitowaniu wiązki laserowej, która po odbiciu od elementu badanego 

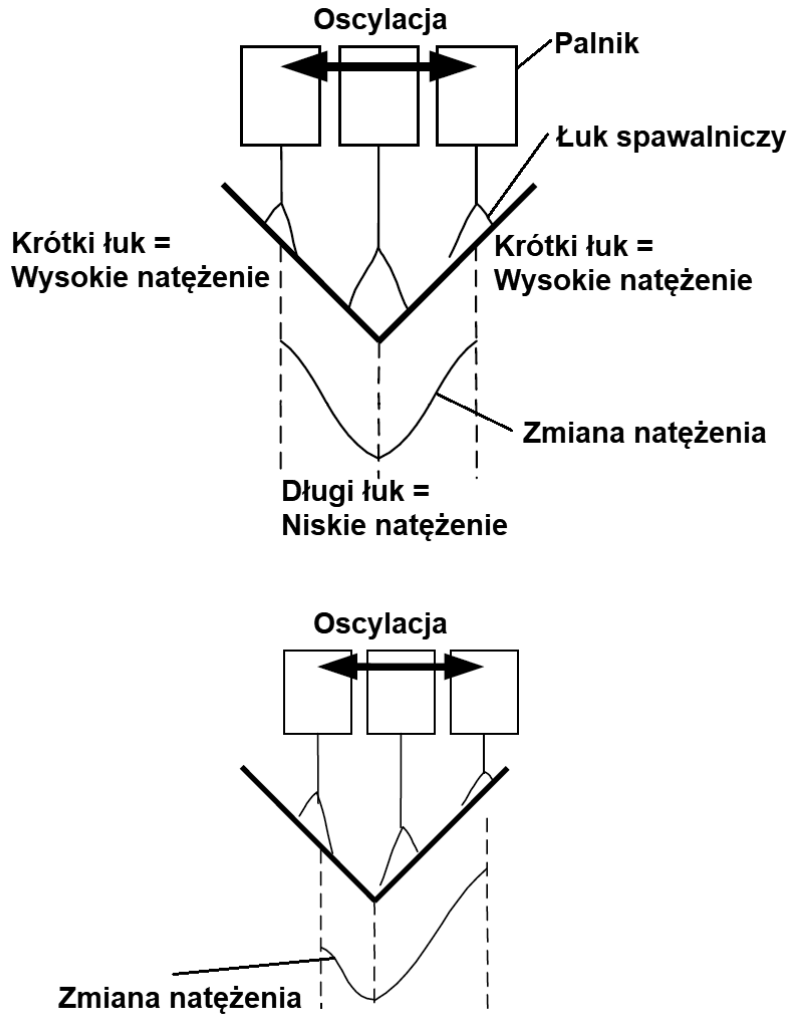

Rys. 9. Sensor łuku - zasada działania

Fig. 9. Arc sensor - principle of operations

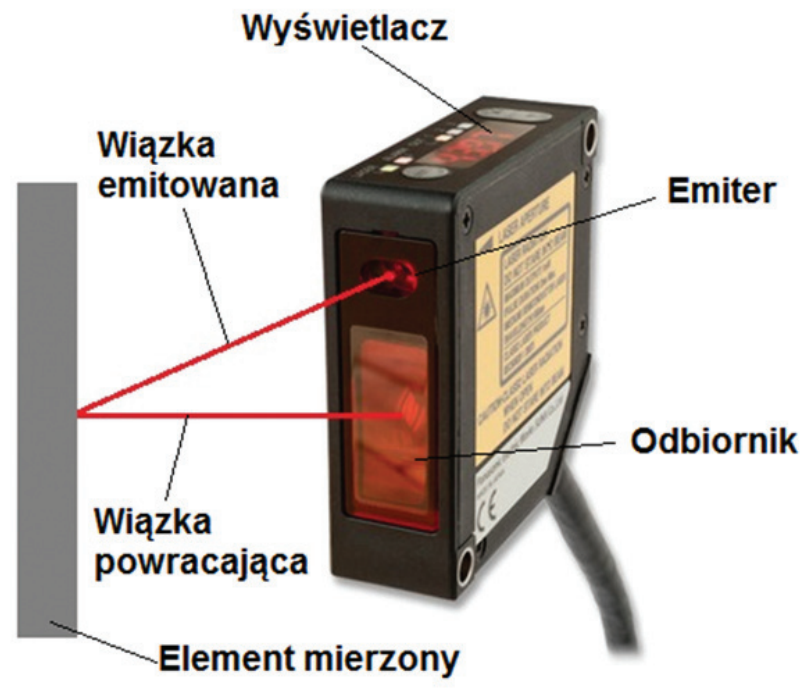

Rys. 10. Sensor laserowy - zasada działania

Fig. 10. Laser sensor - principle of operations

powraca do odbiornika (matryca CMOS). W zależności od przesunięcia elementu badanego wiązka powracająca trafia w różne obszary odbiornika. Dane te przeliczane są na wartości liczbowe odległości pomiędzy sensorem a detalem spawanym. W celu wyznaczenia referenecyjnej odległości sensora od detalu programista ustawia ramię robota na wzorcowym elemencie. Po wejściu wiązki w zakres pracy sensora robot zatrzymuje się (obszar pomiędzy progiem A, a progiem $B$ rys. 11). Miejsce wejścia w zakres pracy określa położenie powierzchni badanej. Programista ma możliwość wejść w zakres pracy z obszaru bliżej sensora przez próg A (odsuwając ramię robota od detalu) lub dalej od sensora przez próg B (przybliżając ramię robota do detalu). Następnie, podczas wykonywania cyklu produkcyjnego robot z zamocowanym sensorem na ramieniu wykonuje ruch liniowy, zbliżając się lub oddalając od elementu spawanego $w$ jednej $z$ osi układu kartezjańskiego X, Y lub Z. Ruch ten możemy wykonać

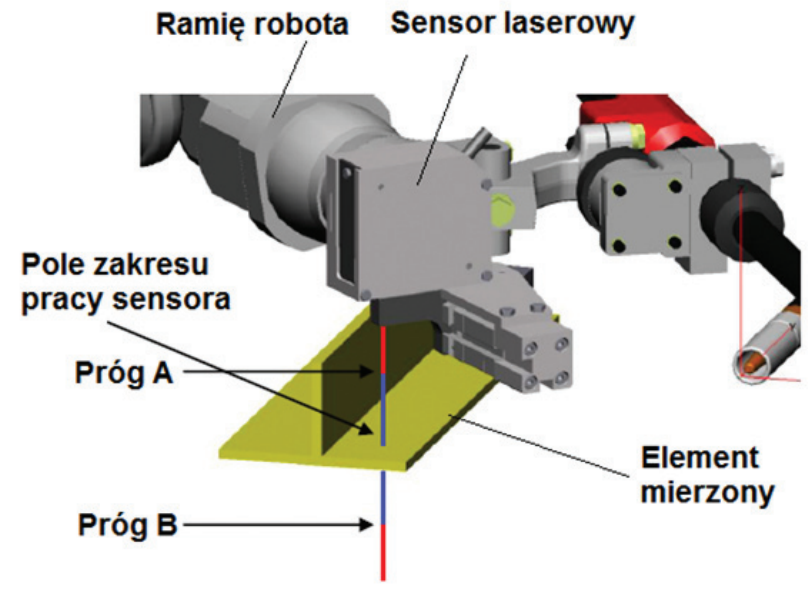

Rys. 11. Wykrywanie elementu sensorem laserowym Fig. 11. Finding element by laser sensor

dla każdej z osi osobno, jeżeli przesunięcia elementu występują we wszystkich trzech kierunkach. Po wejściu w zakres pracy sensora program przelicza wykryte przesunięcia i przesuwa linię spawania.

Referencyjnym punktem pomiarowym może być element niewykonany z metalu będący częścią detalu poza obszarem spawania np. część z tworzywa sztucznego lub element metalowy, który jest odizolowany elektrycznie.

Sensor laserowy sprawdza się również w wąskich przestrzeniach, gdzie utrudnione jest wykorzystanie sensora dotyku, a pomiar może odbyć się z odległości ponad $250 \mathrm{~mm}$.

Podczas spawania elementów wielkogabarytowych częstym problemem jest czystość przygotowanych złączy. Rdza lub zendra, która pokrywa elementy, nie pozwala na użycie sensora dotyku, a sensor łuku staje się niestabilny. Do analizy przesunięć w takich warunkach doskonale sprawdza się sensor laserowy.

\section{Laserowy system wizyjny [6]}

Nowoczesny system wizyjny jest rozszerzeniem możliwości sensora laserowego. Połączenie technologii oświetlania elementu spawanego wiązką laserową z jednoczesną analizą obrazu załamania tej wiązki poprzez kamerę cyfrową daje ogromne możliwości pomiarowe. Oprócz danych dotyczących przesunięć liniowych rozpoznawane są charakterystyczne kształty złączy. W porównaniu do sensora laserowego, który jest bezpośrednio połączony z robotem, system wizyjny potrzebuje dodatkowej jednostki, zazwyczaj komputera PC przetwarzającego on-line wszystkie dane przesyłane do sterownika robota.

Najnowsze generacje systemów wizyjnych oparte są na systemie triangulacji i wykorzystaniu załamania linii laserowej na badanym detalu (rys. 12). Kamera CCD lub CMOS

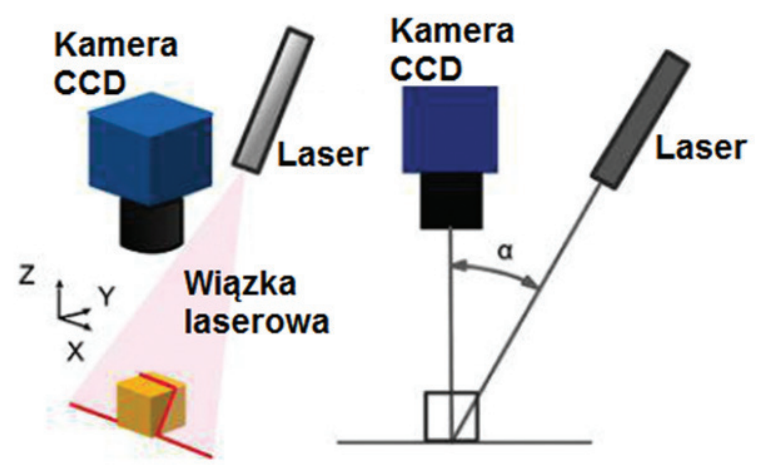

Rys. 12. Triangulacyjny system wizyjny z jedną linią laserową Fig. 12. Triangulation vision system with one laser line 
odczytywała obraz, a komputer analizował za pomocą dedykowanego oprogramowania zakrzywienia linii. Dzięki takiej technologii można było stworzyć obraz trójwymiarowy, czyli przesunięcie $X, Y$ oraz $Z$ w układzie kartezjańskim podczas każdego próbkowania. Dużą zaletą tego rozwiązania jest to, że nie jest podatne na otaczające światło rozproszone ze względu na zastosowanie wiązki laserowej. Układ ten wyznacza również bardzo precyzyjnie wartość „głębokości", czyli odległość od kamery do detalu mierzonego. Jednak pomimo wielu zalet system ten ma kilka wad jak; wysoka czułość na odbicia wiązki przy badaniu elementów refleksyjnych oraz dostarczanie obrazu z małą ilością danych (załamanie jednej linii laserowej nie pozwoli np. na uzyskanie informacji o położeniu początku spoiny). Nowa generacja triangulacyjnych laserowych systemów wizyjnych oparta jest na ruchu kołowym wiązki laserowej, czyli CSS (ang. Circular Scanning Sensor). Przy dużej prędkości wirowania daje obraz okręgu na detalu spawanym (rys. 13). Załamania tego okręgu są analizowane przez dedykowany software zainstalowany na komputerze, a następnie przesłane do sterownika robota.

Tego typu metoda skanowania jest nieczuła na refleksy i z powodzeniem może być wykorzystana nawet przy badaniu stali nierdzewnej czy aluminium.

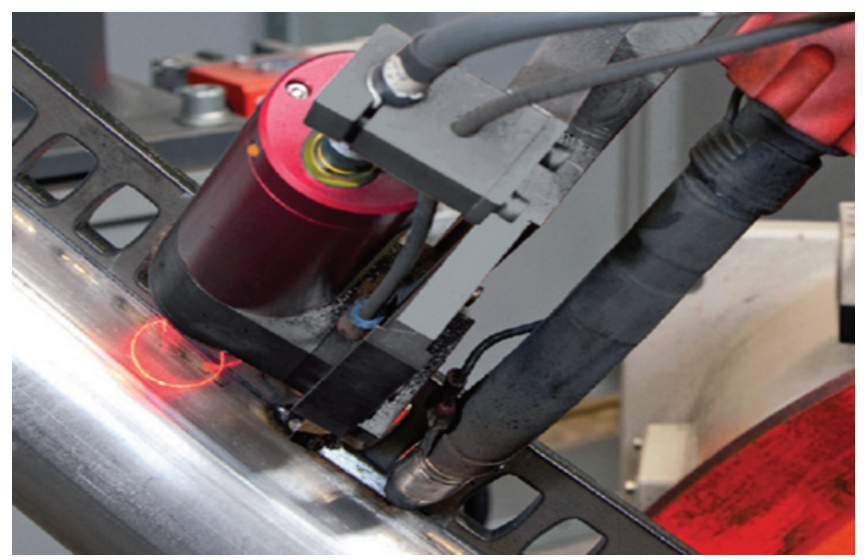

Rys. 13. Triangulacyjny laserowy system wizyjny z kołową wiązką skanującą [6]

Fig. 13. Triangulation laser vision system with circular scanning beam [6]
W przypadku robotów spawalniczych firmy PANASONIC stosowany jest kompatybilny sprzętowo i programowo system wizyjny ARC-EYE CSS. Szukanie ścieżki spawania może się odbywać zarówno przed procesem spawania, jak i w jego trakcie.

Programista piszący program ma do wyboru obszerną bibliotekę złączy spawanych i spoin (rys. 14). Takie rozwiązanie znacznie przyspiesza pracę. W spoinach wielościegowych system ARC-EYE CSS wykorzystywany jest do analizy pierwszego ściegu. Posiada funkcje programowe do znajdowania oraz analizy rowka spawalniczego w złączach doczołowych oraz kątowych z ukosowaniem blach.

Wykrywa nie tylko środek złącza, ale również jego szerokość. Pozwala to na dobór odpowiedniej częstotliwości oraz amplitudy ruchu zakosowego. Dlatego z powodzeniem może być wykorzystany w aplikacjach zrobotyzowanych do produkcji elementów wielkogabarytowych. Sensor ten jest nieczuły na zabrudzenia elementów, a w przypadku stali o błyszczącej powierzchni jest nieczuły na refleksy. Dodatkowo w przypadku spawania miejsc trudnodostępnych głowicę skanującą po wykonaniu pomiaru można automatycznie odłożyć do stacji zmiany narzędzi, a po wykonaniu procesu spawania pobrać ją ponownie.

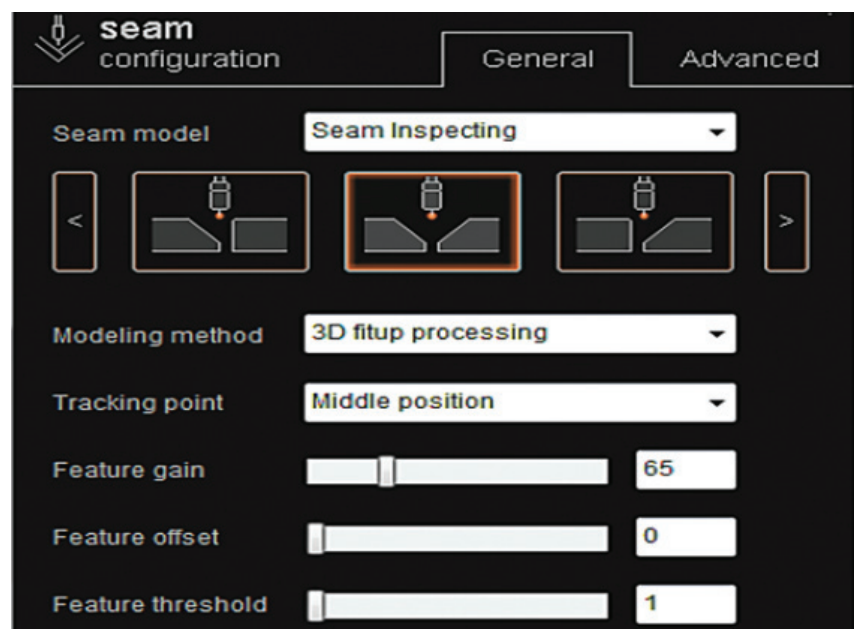

Rys. 14. Biblioteka złączy spawanych systemu ARC-EYE [6] Fig. 14. A library of welding joints in ARC-EYE system [6]

\section{Wnioski}

1. Każdy sensor znajduje zastosowanie w określonych aplikacjach i złączach spawanych.

2. Nie ma uniwersalnego sensora, który sprawdzi się we wszystkich warunkach.

3. Dobór odpowiedniego sensora zależy głównie od doświadczenia integratora budującego system zrobotyzowany. To on widząc złożoność kształtu detalu i warunki jakościowe, które musi spełniać detal po spawaniu, dobiera odpowiedni osprzęt.

4. Przy wykrywaniu prostych przesunięć wystarczające są sensory dotyku oraz łuku. Są to stosunkowo tanie rozwiązania w porównaniu z laserowymi systemami wizyjnymi.

5. Do analizy złożonych kształtów i wykrywania cech obiektów niezastąpione są laserowe systemy wizyjne. Szeroki wachlarz funkcji pozwala na zastosowanie ich praktycznie w każdej aplikacji.

\section{Literatura}

[1] Pfeifer T.: Rozwój rynku robotów przemysłowych w Polsce i na świecie, Przegląd Spawalnictwa 8/2011.

[2] Nowak M., Buchowski J., Wiśniewski D.: Zrobotyzowane spawanie wielkogabarytowych elementów ze wspomaganiem programowania off-line, Przegląd Spawalnictwa nr 10/2013.
[3] Materiały własne firmy PANASONIC.

[4] Materiały własne firmy DINSE.

[5] Ferenc K.: Podręcznik spawania. Zagadnienia ogólne, Warszawa 2016.

[6] www.arc-eye.com/en 